\title{
PENGARUH PROPORSI GULA DAN PEKTIN PADA PEMBUATAN PERMEN JELLY CARICA (Carica Pubescens L.)
}

\author{
The Effect of Pectin and Sugar Proportion on Production Jelly Candy Carica (Carica \\ Pubescens L.)
}

\author{
M. Nuzul Minggi* dan Muh. Aniar Hari Swasono \\ Prodi Ilmu dan Teknologi Pangan, Fakultas Pertanian, Universitas Yudharta Pasuruan \\ *Penulis korespondensi, email : nuzul33.mnm@gmail.com
}

\begin{abstract}
The fruit of Carica pubescens has several distinctive features compared to Carica papaya is typical flavored fruit, smaller size, thinner flesh with a slightly orange yellow color and sour taste. So that the need for innovative carica processing is jelly carica candy which is a candy from extract of carica fruit with additional proportion of pectin and sugar. The method used is Factorial Random Design (RAK) which consists of 2 factors. The factor 1 of the proportion of pectin $(P)$ consists of 2 levels, namely 40gr and 60gr. Factor 2 proportion of sugar $(G)$ consists of 3 levels, namely $0 \mathrm{gr}, 20 \mathrm{gr}$ and $50 \mathrm{gr}$ so there are 6 treatment combinations, each of which is repeated 2 times. Result of effectiveness index analysis found in treatment of P2G2 (proportion of pectin $60 \mathrm{gr}$ and sugar $20 \mathrm{gr}$ )namely water content with a value of $65.06 \%$, total sugar with value $7.74 \%$, vitamin C with value $11.50 \mathrm{mg} / 100 \mathrm{~g}$, flavor with value 3,55 (neutral), aroma with value 3,25 (neutral), color with value 3,60 (neutral) and texture with value 3.50 neutral. Data analysis using ANOVA with $1 \%$ and $5 \%$ confidence interval, if an influence is found on one of the variables then it is followed by a BNT test (5\%). Observations made include physicochemical test ie water content with gravimetric method, total sugar by UV-Vis Spectrophotometric method, vitamin $C$ with Iodimetri Titrasi method and organoleptic test of taste, aroma, color and texture.
\end{abstract}

Keywords: proportion of pectin, sugar, candy jelly carica

\begin{abstract}
ABSTRAK
Buah Carica pubescens memiliki beberapa perbedaan ciri dibanding dengan Carica papaya yaitu buah beraroma khas, ukuran lebih kecil, daging buah lebih tipis dengan warna kuning sedikit jingga dan rasanya masam. Sehingga perlu adanya inovasi pengolahan carica yaitu permen jelly carica yang merupakan permen dari ekstrak buah carica dengan tambahan proporsi pektin dan gula. Metode yang digunakan adalah Rancangan Acak Kelompok (RAK) faktorial yang terdiri dari 2 faktor. Faktor 1 proporsi pektin (P) terdiri dari 2 level yaitu 40gr dan 60gr. Faktor 2 proporsi gula (G) terdiri dari 3 level yaitu $0 \mathrm{gr}$, 20gr dan 50gr sehingga terdapat 6 kombinasi perlakuan yang masing masing diulang 2 kali. hasil analisa indeks efektifitas terdapat pada perlakuan P2G2 (Proporsi pektin 60 gr dan gula 20 gr) yaitu kadar air dengan nilai 65,06 $\%$, total gula dengan nilai 7,74 \%, vitamin C dengan nilai $11,50 \mathrm{mg} / 100 \mathrm{~g}$, rasa dengan nilai 3,55 (netral), aroma dengan nilai 3,25 (netral), warna dengan nilai 3,60 (netral) dan tekstur dengan nilai 3,50 netral. Analisis data menggunakan ANOVA dengan selang kepercayaan 1\% dan 5\%, apabila ditemukan pengaruh terhadap salah satu variabel maka dilanjutkan dengan uji BNT (5\%). Pengamatan yang dilakukan meliputi uji fisikokimiawi yaitu kadar air dengan metode gravimetri, total gula dengan metode Spektrofotometri UV-Vis, vitamin C dengan metode Iodimetri Titrasi dan uji organoleptik yaitu rasa, aroma, warna dan tekstur.
\end{abstract}

Kata kunci: proporsi pektin, gula, permen jelly carica 


\section{PENDAHULUAN}

Carica pubescens Lenne \& K. Koch merupakan salah satu tanaman khas dataran tinggi di Indonesia dengan kandungan vitamin $\mathrm{C}$ tinggi yang berpotensi sebagai bahan alami dalam penyembuhan mukosa mulut. Di Indonesia, spesies ini biasa dikenal dengan sebutan "karika", dapat dijumpai di kawasan Bromo dan Cangar Jawa Timur, serta Dataran Tinggi Dieng, Jawa Tengah. (Minarno, 2015)

Buah dari tanaman ini telah diteliti kandungannya sebagai zat antioksidan dan sumber flavanoid. Flavonoid adalah senyawa yang terdiri dari 15 atom karbon yang umumnya tersebar di dunia tumbuhan. Flavonoid tersebar luas di tanaman mempunyai banyak fungsi. Flavonoid adalah pigmen tanaman untuk memproduksi warna bunga merah atau biru pigmentasi kuning pada kelopak yang digunakan untuk menarik hewan penyerbuk. Flavonoid hampir terdapat pada semua bagian tumbuhan termasuk buah, akar, daun dan kulit luar batang (Lumbessy, 2013). Untuk memanfaatkan dan meningkatkan potensi carica maka dibuat produk baru berupa jelly.

Permen jelly merupakan permen yang dibuat dari air atau sari buah dan bahan pembentuk gel. Permen jelly berpenampilan jernih transparan serta mempunyai tekstur dengan kekenyalan tertentu. (Malik, 2010 dalam Neswati, 2013).

Penelitian yang berjudul "Pengaruh Proporsi pektin dan gula terhadap kadar air, total gula dan vitamin $\mathrm{C}$ "permen jelly carica" (Carica Pubescens L.)" ini bertujuan untuk mengetahui perlakuan proporsi pektin dan gula terbaik dilihat dari faktor fisikokimiawi dan organoleptik pada permen jelly carica.

\section{METODE PENELITIAN}

\section{Bahan}

Bahan yang digunakan adalah buah carica (Carica Pubescens L.) yang di beli di petani desa tengger bromo jawa timur, Gula tebu sukrosa, Pektin, Gelatin dan Natrium benzoat.

\section{Alat}

Alat yang digunakan adalah Pisau berfungsi untuk mengupas dan memotong carica (Carica Pubescens L.), Panci berfungsi untuk wadah pemasakan bahan, Kompor berfungsi sebagai alat pemanas atau pembakar, Termometer alat ini berfungsi untuk melihat ukuran suhu, Kain kasa berfungsi untuk penyaringan ektraksi dari daging buah carica (Carica Pubescens L.), Gelas ukur alat ini berfungsi untuk mengukur takaran air dan ekstraksi daging buah carica(Carica Pubescens L.), Timbangan berfungsi untuk menimbang / mengukur bahan yang dibutuhkan, Pengaduk kayu alat ini berfungsi untuk mengaduk adonan, loyang berfungsi untuk wadah pendinginan adonan yang sudah jadi.

\section{Rancangan Percobaan}

Percobaan dilakukan dengan menggunakan Rancangan Acak Kelompok (RAK) faktorial yang terdiri dari 2 faktor. Faktor 1 proporsi pektin (P) yang terdiri dari 2 level yaitu 40gram dan 60gram. Faktor 2 proporsi gula $(G)$ yang terdiri dari 3 level yaitu tanpa gula, 20gram, 50gram. Terdapat 6 kombinasi perlakuan yang masing masing diulang 2 kali.

P1 X G1 = Proposi pektin 40gram dan 0gram /300gram ekstrak carica

P1 X G2 = Proposi pektin 40gram dan gula 20gram / 300gram ekstrak carica

P1 X G3 = Proposi pektin 40gram dan gula 50gram / 300gram ekstrak carica P2 X G1 = Proposi pektin 60gram dan 0gram / 300gram ekstrak carica P2 X G2 = Proposi pektin 60gram dan gula 20gram / 300gram ekstrak carica P2 X G3 = Proposi pektin 60gram dan gula 50gram / 300gram ekstrak carica

\section{Tahap Penelitian}


Sortasi dan penggolongan mutu sangat diperlukan untuk menggolongkan bahan pangan sesuai dengan ukuran dan tidak adanya cacat. Standar mutu ditetapkan berdasarkan ukuran bahan pangan, bobot, kebersihan, kemasakan, bebas dari bahan asing, serta bebas dari cacat. Pengertian cacat termasuk cacat fisik, mekanik, mikrobiologis, maupun cacat yang disebabkan serangga (satuhu, 1996 dalam almahbub, 2017).

Towing / Pencucian Bahan dicuci dengan air bersih mengalir bertujuan untuk menghilangkan kotoran yang terdapat pada bahan. Bahan dasar yang digunakan pada penelitian ini adalah buah carica (Carica Pubescens L.).

Pemotongan buah yang telah dicuci lalu dipotong menjadi kotak seukuran dadu selanjutnya Penimbangan buah yang telah dipotong lalu ditimbang 300gram untuk proses selanjutnya. Pencampuran setelah buah ditimbang / 300 gram di-dicampur dengan mesin blender setelah itu ekstraksi buah yang telah dihaluskan kemudian disaring menggunakan kain kasa selanjutnya pemasakan, ekstraksi buah carica dimasak dengan kompor menggunakan suhu $\pm 70^{\circ} \mathrm{C}$ dengan terus diaduk. Setelah itu masukan gula setelah meleleh ditambahkan pektin sesuai dengan perlakuan yang telah ditentukan, gelatin 5 gram dan nattrium benzoat 1 gram yg berfungsi untuk menambah daya simpan sambil diaduk hingga mendidih.

Pengentasan, adonan yang telah mendidih diletakkan pada loyang dan didiamkan pada suhu ruang hingga jadi permen jelly proses selanjutnya pemotongan, adonan yang sudah menjadi permen jelly dipotong kotak persegi seukuran dadu.

Tahap penyelesaian yaitu permen jelly carica (Carica Pubescens L.) yang sudah dingin kemudian dikemas dengan baik. Pengemasan merupakan salah satu cara untuk melindungi atau mengawetkan produk pangan maupun non pangan. Kemasan adalah suatu wadah atau tempat yang digunakan untuk mengemas suatu produk yang dilengkapi dengan label atau keterangan - keterangan termasuk beberapa manfaat dari isi kemasan (Susanto dan Saneto,1994)

\section{Metode Pengumpulan Data}

Metode pengumpulan data yang digunakan pada penelitian ini adalah dengan melakukan pengamatan pada fisikokimiawi dan organoleptik. Uji fisikokimiawi meliputi kadar air, total gula dan vitamin C. Karakteristik organoleptik yang meliputi penilaian terhadap rasa, aroma, tekstur, dan warna. Data yang meliputi karakteristik fisikokimiawi diperoleh dari laboratorium, sedangkan data karakteristik organoleptik diperoleh dari pengisian skor kesukaan oleh panelis 20 orang bukan ahli. Skala nilai kesukaan mulai 1 (sangat tidak suka) sampai 5 (sangat suka).

\section{Metode Analisa Data}

Analisa data dilakukan secara ANOVA dengan selang kepercayaan 5\% dan $1 \%$. Apabila ditemukan pengaruh nyata terhadap salah satu variabel maka dilanjutkan dengan uji beda nyata terkecil (BNT) 5\%. Untuk uji organoleptik menggunakan uji Friedman. Perlakuan terbaik menggunakan indeks efektivitas (Susrini,2003)

\section{HASIL DAN PEMBAHASAN}

\section{Kadar Air}

Daya tahan dan kesegaran suatu produk pangan sangat dipengaruhi oleh kandungan air didalamnya. Air merupakan komponenpenting dalam suatu bahan makanan karena air dapat mempengaruhi kenampakan, tekstur dan cita rasa makanan (Winarno, 1984). Hasil analisa kadar air pada permen jelly terhadap nilai kadar air pada (tabel 4.1).

Tabel 1 Rerata hasil nilai kadar air permen jelly carica

Perlakuan Kadar




\begin{tabular}{cc}
\hline & Air \\
\hline P1G1 Proporsi pektin 40 gr dan gula 0 gr & $76,49^{\mathrm{d}}$ \\
P1G2 Proporsi pektin 40 gr dan gula 20 gr & $68,58 \mathrm{~b}^{\mathrm{c}}$ \\
P1G3 Proporsi pektin 40 gr dan gula 50 gr & $65,46^{\mathrm{b}}$ \\
P2G1 Proporsi pektin 60 gr dan gula 0 gr & $69,05^{\mathrm{c}}$ \\
P2G2 Proporsi pektin 60 gr dan gula 20 gr & $65,06^{\mathrm{ab}}$ \\
P2G3 Proporsi pektin 60 gr dan gula 50 gr & $60,83^{\mathrm{a}}$ \\
\hline
\end{tabular}

Dari hasil tabel 1 menunjukan kadar air terendah terdapat pada perlakuan P2G3 poporsi pektin 60 gr dan gula 50 gr dengan nilai 60,83 dan tertinggi terdapat pada perlakuan P1G1 proporsi pektin 40 gr dan gula 0 gr dengan nilai 76,49.

Berdasarkan hasil analisa kadar air terlihat semakin menurun. Menurut Karjono (1991) pektin adalah senyawa polimer yang dapat mengikat air, membentuk gel atau mengentalkan cairan. Sifat inilah yang dapat dimanfaatkan sehingga selain untuk jelly, pektin juga dipakai dalam industri daging dan produk pangan lainnya yang membutuhkan pengikat air. Tabel 1 Persentase kadar air tersebut menunjukkan bahwa kadar air dapat diturunkan jika konsentrasi sukrosa dan pektin dinaikkan sehingga pengental akan menjadi membentuk gel yang semakin kuat.. Menurut Salamah et al. (2006) kadar air yang rendah dalam permen jelly disebabkan oleh karena proses pengadukan yang merata sehingga penguapan air besar. Penggunaan sukrosa dan glukosa dapat menyerap dan mengikat air pada produk sehingga dapat menurunkan kandungan air dalam produk. Penambahan gula akan mempengaruhi keseimbangan pektin air yang ada dan meniadakan kemantapan pektin. Hal ini disebabkan karena gula sebagai senyawa pendehidrasi, akibatnya ikatan antara pektin dan gula akan lebih kuat dan menghasilkan jaringan molekul polisakarida yang kompleks (Gliksman, 1969).

\section{Total Gula}

Menurut Nicol (1982), sukrosa mempunyai sifat-sifat yang menonjol antara lain mempunyai rasa manis yang sangat diinginkan, dapat berperan sebagai bulking agent, mempunyai tingkat kelarutan yang tinggi, dan pengawet yang baik. Sukrosa akan membentuk flavor dan warna pada saat pemanasan, mempunyai daya simpan yang baik, mudah dicerna, dan tidak beracun. Selain itu, sukrosa juga murah, tidak berwarna, mempunyai kemurnian yang tinggi baik dari sifat kimia maupun mikrobiologi.

Tabel 2 Rerata hasil nilai total gula permen jelly carica

\begin{tabular}{lc}
\hline Perlakuan & $\begin{array}{c}\text { Total } \\
\text { Gula }\end{array}$ \\
\hline P1G1 Proporsi pektin 40 gr dan gula 0 gr & $2,55^{\mathrm{b}}$ \\
P1G2 Proporsi pektin 40 gr dan gula 20 gr & $8,52^{\mathrm{d}}$ \\
P1G3 Proporsi pektin 40 gr dan gula 50 gr & $16,53^{\mathrm{f}}$ \\
P2G1 Proporsi pektin 60 gr dan gula 0 gr & $1,36^{\mathrm{a}}$ \\
P2G2 Proporsi pektin 60 gr dan gula 20 gr & $7,74^{\mathrm{c}}$ \\
P2G3 Proporsi pektin 60 gr dan gula 50 gr & $12,40^{\mathrm{e}}$ \\
\hline
\end{tabular}

Dari hasil tabel 2 menunjukan total gula terndah terdapat pada perlakuan P2G1 Proporsi pektin 60 gr dan gula 0 gr dengan nilai 1,36 dan tertinggi terdapat pada perlakuan P1G3 Proporsi pektin 40 gr dan gula 50 gr dengan nilai 16,53 . Semakin tinggi konsentrasi pektin dan sukrosa yang diberikan maka semakin tinggi total gula yang dihasilkan.

Perhitungan analisis ragam ANOVA total gula permen jelly carica menunjukkan bahwa pengaruh konsentrasi pektin dan konsentrasi sukrosa berbeda nyata. Terdapat interaksi antara konsentrasi pektin dengan konsentrasi sukrosa terhadap total gula. Dari tabel diatas menunjukan bahwa semakin tinggi konsentrasi gula maka semakin tinggi total gula yang dihasilkan seperti yang dikemukakan oleh Luthony (1990) dalam Pratama (2011) bahwa total gula akan mengalami peningkatan jika konsentrasi gula yang diberikan juga semakin besar. Karena larutan gula yang ada merupakan larutan gula yang terdiri dari sebagian besar sukrosa dan beberapa diantanya non sukrosa. Sehingga dengan penambahan gula 
dapat menambah bagian sukrosa yang terdapat dalam sari buah. nilai rerata hasil uji permen jelly carica dengan pengaruh proporsi pektin dan gula berbeda nyata terhadap total gula permen jelly carica.

\section{Vitamin C}

Vitamin C diproduksi oleh tumbuhan dalam jumlah yang besar. Fungsi vitamin $\mathrm{C}$ bagi tumbuhan adalah sebagai agen antioksidan yang dapat menetralkan singlet oksigen yang sangat reaktif, berperan dalam pertumbuhan sel, berfungsi seperti hormon, dan ikut berperan dalam proses fotosintesis (Davey, 2006).

Tabel 3 Rerata hasil nilai vitamin $\mathrm{C}$ permen jelly carica

\begin{tabular}{|c|c|}
\hline Perlakuan & $\begin{array}{c}\text { Vitamin } \\
\mathrm{C}\end{array}$ \\
\hline P1G1 Proporsi pektin 40 gr dan gula $0 \mathrm{gr}$ & $5,80^{\mathrm{a}}$ \\
\hline P1G2 Proporsi pektin 40 gr dan gula $20 \mathrm{gr}$ & $10,30^{\mathrm{c}}$ \\
\hline P1G3 Proporsi pektin $40 \mathrm{gr}$ dan gula $50 \mathrm{gr}$ & $8,50^{\mathrm{ab}}$ \\
\hline P2G1 Proporsi pektin $60 \mathrm{gr}$ dan gula $0 \mathrm{gr}$ & $9,35^{\mathrm{b}}$ \\
\hline P2G2 Proporsi pektin $60 \mathrm{gr}$ dan gula $20 \mathrm{gr}$ & $11,50^{\mathrm{d}}$ \\
\hline P2G3 Proporsi pektin $60 \mathrm{gr}$ dan gula $50 \mathrm{gr}$ & $12,55^{\mathrm{e}}$ \\
\hline
\end{tabular}

Dari hasil tabel 3 menunjukan vitamin C terndah terdapat pada perlakuan P1G1 proporsi pektin 40 gr dan gula 0 gr dengan nilai 5,80 dan tertinggi terdapat pada perlakuan P2G3 Proporsi pektin 60 gr dan gula 50 gr dengan nilai 12,55 .

Vitamin $C$ hanya dapat dibentuk oleh tumbuhan dan terdapat pada sayuran serta buah-buahan dalam jumlah yang besar. Hal ini disebabkan karena tumbuhan memiliki enzim mikrosomal Lgulonolakton oksidase, sebagai komponen dalam pembentukan asam askorbat (Nasoetion \& Karyadi, 1987 dan Padayatty et al., 2003). C. pubescens terbukti mengandung vitamin $\mathrm{C}$ dan memiliki aktivitas antioksidan karena mengandung flavonoid (Fatchurrozak dkk, 2013; Laily, 2012). Hasil uji vitamin C permen jelly carica menunjukan berbeda sangat nyata dimana semakin tinggi perlakuan konsentrasi pektin dan gula menghasilkan vitamin $\mathrm{C}$ semakin tinggi, namun terdapat perbedaan dimana perlakuan P1G2 pektin 40 gr dan gula 20 gr tingkat vitamin $\mathrm{C}$ nya lebih tinggi dibandingkan P1G3 pektin 40 gr dan gula 50 gr hal ini menunjukan bahwa untuk sekala industri maupun rumahan untuk tingkat vitamin $\mathrm{C}$ lebih menguntungkan menggunakan perlakuan $\mathrm{P} 1 \mathrm{G} 2$ dengan perbandingan pektin 40 gr dan gula $20 \mathrm{gr}$ dibandingkan menggunakan perlakuan P1G3 pektin 40 gr dan gula 50 gr. Secara biokimia vitamin $\mathrm{C}$ mempunyai berbagai peran yaitu: memperkaya reduktan biologi sebagai suatu kofaktor penting untuk reaksireaksi reduksi logam seperti besi dan tembaga, sebagai suatu antioksidan protektif, kofaktor reduktif untuk hydroksilasi selama pembentukan kolagen, berperan dalam fungsi sistem oksigenasi, biosintesis karnitin, dan meningkatkan penyerapan serta metabolisme zat besi (Jacob, 2005).

\section{Analisa Organoleptik}

Pengujian organoleptik adalah uji penerimaan (preference test), yaitu uji hedonik. Tujuan uji ini adalah untuk mengetahui apakah suatu komoditi dapat diterima oleh masyarakat, panelis diminta tanggapan tentang kesukaan atau ketidaksukaan pada komoditi tersebut (Afriani, 2011). Uji organoleptik terhadap permen jelly carica dilakukan oleh 20 orang panelis bukan ahli. Produk yang diujikan terdiri dari 6 sampel permen jelly carica dengan perlakuan berbeda.

\section{Rasa}

Dari hasil produk permen jelly carica menghasilkan nilai kesukaan panelis pada uji rasa berkisar antara 2,05 (tidak suka) sampai dengan 3,85 (suka). Berdasarkan analisis statistik proporsi pektin dan gula terhadap rasa permen jelly carica berbeda nyata (X2 tabel $<$ X hitung). 


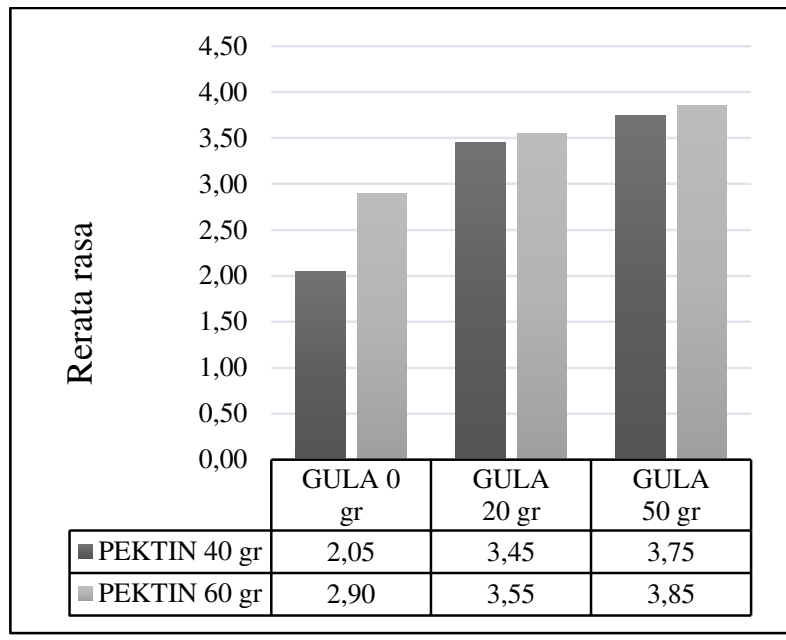

Gambar 1 Rerata rasa permen jelly carica

Nilai kesukaan panelis pada uji organoleptik rasa menunjukan nilai terendah pada perlakuaan Pektin 40 gr gula 0 gr (tanpa gula) (P1G1) dengan nilai 2,05 (tidak suka) sementara nilai tertinggi terdapat pada perlakuaan Pektin 60 gr dan Gula 50 gr (P2G3) dengan nilai 3,85 (suka) dan dengan rata-rata skor 4,33. Gambar 1 menunjukan, kesukaan panelis terhadap rasa permen jelly carica dengan perlakuaan pektin 60 gr dan gula 50 gr (P2G3). Pada gambar 1 menunjukan peningkatan rasa manis permen jelly carica hal ini diduga karena dengan penambahan sukrosa mampu membentuk citarasa yang baik karena kemampuannya menyeimbangkan rasa asam, pahit atau asin, Hal ini terjadi karena rasa dipengaruhi oleh beberapa faktor yaitu senyawa kimia, suhu, konsentrasi dan interaksi dengan komponen rasa yang lain (Winarno, 2008).

\section{Aroma}

Dari hasil produk permen jelly carica menghasilkan nilai kesukaan panelis pada uji aroma berkisar antara 3,00 (tidak suka) sampai dengan 3,45 (suka). Berdasarkan analisis statistik proporsi pektin dan gula terhadap aroma permen jelly carica tidak berbeda nyata (X2 tabel $>\mathrm{X}$ hitung).

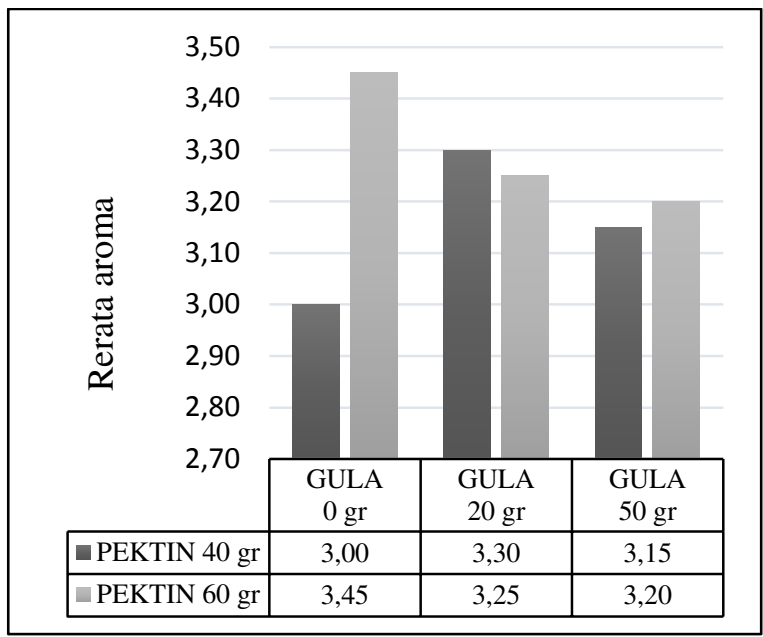

Gambar 2 Rerata aroma permen jelly carica

Nilai kesukaan panelis pada uji organoleptik aroma menunjukan nilai g 0 gr (tanpa gula) (P1G1) dengan nilai 3,00 (tidak suka) sementara nilai tertinggi terdapat pada perlakuaan Pektin 60 gr dan gula 0 gr (tanpa gula) (P2G1) dengan nilai 3,45 (suka) dengan rata-rata skor 4,03. Gambar 2 menunjukan semakin tinggi konsentrasi pektin maka semkin menurun tingkat aroma yang didapat dan semakin tinggi tingkat konsentrasi gula maka semakin tinggi tingkat aroma permen jeli yang dihasilkan. Hal ini dikarenakan, sukrosa dapat memperbaiki aroma dan cita rasa dengan cara membentuk keseimbangan yang lebih baik antara keasaman, rasa pahit dan rasa asin, ketika digunakan pada pengkonsentrasian larutan (Nicol, 1979). Aroma dan cita rasa akan menjadi lebih menonjol dengan memperhatikan tingkat kemanisan yang digunakan (Pancoast dan Junk, 1980). Dari gambar diatas menunjukan bahwa aroma tertinggi diperoleh dari hasil penambahan gula 20 gr hal ini baik digunakan untuk sekala industri maupun rumahan.

\section{Warna}

Dari hasil produk permen jelly carica menghasilkan nilai kesukaan panelis pada uji warna berkisar antara 3,30 (tidak suka) sampai dengan 3,70 (suka). Berdasarkan analisis statistik proporsi pektin dan gula 
terhadap warna permen jelly carica tida berbeda nyata (X2 tabel $>$ X hitung).

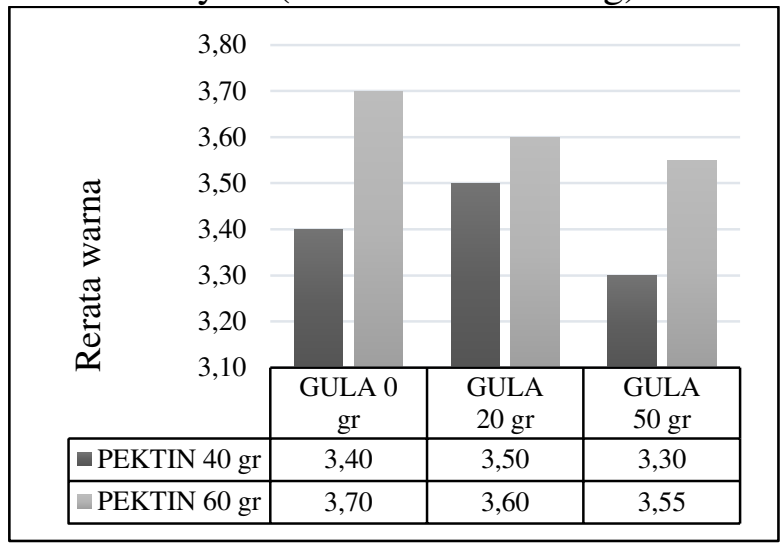

Gambar 3 Rerata warna permen jelly carica

Nilai kesukaan panelis pada uji organoleptik warna menunjukan nilai terendah pada perlakuaan Pektin 40 gr dan Gula 50 gr (P1G3) dengan nilai 3,30 (tidak suka) sementara nilai tertinggi terdapat pada perlakuaan Pektin 60 gr Gula 0 gr (tanpa gula) (P2G1) dengan nilai 3,70 (suka) dengan rata-rata skor 3,98. Gambar 3 menunjukan semakin tinggi konsentrasi pektin maka semkin menurun tingkat warna yang didapat dan semakin tinggi tingkat konsentrasi gula maka semakin tinggi tingkat warna permen jeli yang dihasilkan. Hal ini dikarenakan, sukrosa dapat memperbaiki aroma dan cita rasa dengan cara membentuk keseimbangan yang lebih baik antara keasaman, rasa pahit dan rasa asin, ketika digunakan pada pengkonsentrasian larutan (Nicol, 1979). Aroma dan cita rasa akan menjadi lebih menonjol dengan memperhatikan tingkat kemanisan yang digunakan (Pancoast dan Junk, 1980). Namun terdapat juga tingkat konsentrasi gula yg tinggi tetapi tingkat warna merendah disimpulkan dari gambar diatas menunjukan bahwa warna tertinggi diperoleh dari hasil penambahan gula $20 \mathrm{gr}$ hal ini baik digunakan untuk sekala industri maupun rumahan.

\section{Tekstur}

Dari hasil produk permen jelly carica menghasilkan nilai kesukaan panelis pada uji tekstur berkisar antara 2,35 (tidak suka) sampai dengan 3,95 (suka). Berdasarkan analisis statistik proporsi pektin dan gula terhadap tekstur permen jelly carica berbeda nyata (X2 tabel $<\mathrm{X}$ hitung).

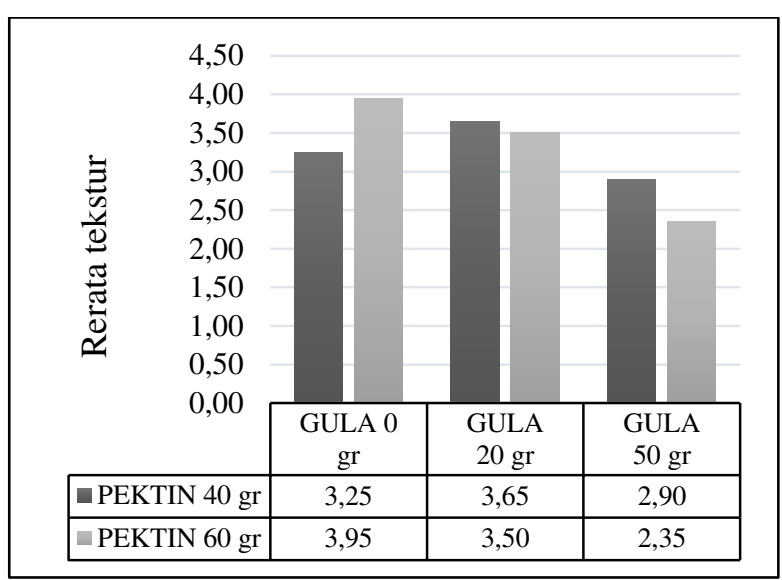

Gambar 4 Rerata rasa permen jelly carica

Nilai kesukaan panelis pada uji organoleptik tekstur menunjukan nilai terendah pada perlakuaan Pektin 60 gr dan Gula 50 gr (P2G3) dengan nilai 2,35 (tidak suka) sementara nilai tertinggi terdapat pada perlakuaan Pektin 60 gr dan Gula 0 gr (tanpa gula) (P2G1) dengan nilai 3,95 (suka) dengan rata-rata skor 4,63. Gambar 4 menunjukan, kesukaan panelis terhadap tekstur permen jelly carica dengan perlakuaan pektin 60 gr dan Gula 0 gr (tanpa gula) (P2G1). Hal ini terjadi karena adanya pelunakan hidrolisis poliskarida pada dinding sel, termasuk juga terhidrolisisnya protopektin menjadi pektin yang larut sehingga daya rekat antar sel berkurang dan buah menjadi lunak (Eskin et al. 1971).

\section{Perlakuan Terbaik Fisikokimiawi dan Organoleptik}

Hasil perhitungan indeks efektivitas menunjukkan kombinasi perlakuan terbaik pada P2G2 (Proporsi pektin 60 gr dan gula 20 gr) yaitu kadar air dengan nilai 65,06\%, Total gula dengan nilai 7,74\%, Vitamin C dengan nilai $11,50 \mathrm{mg} / 100 \mathrm{~g}$, Rasa dengan nilai 3,55 (netral), Aroma dengan nilai 3,25 (netral), Warna dengan nilai 3,60 (netral) dan Tekstur dengan nilai 3,50 netral. 


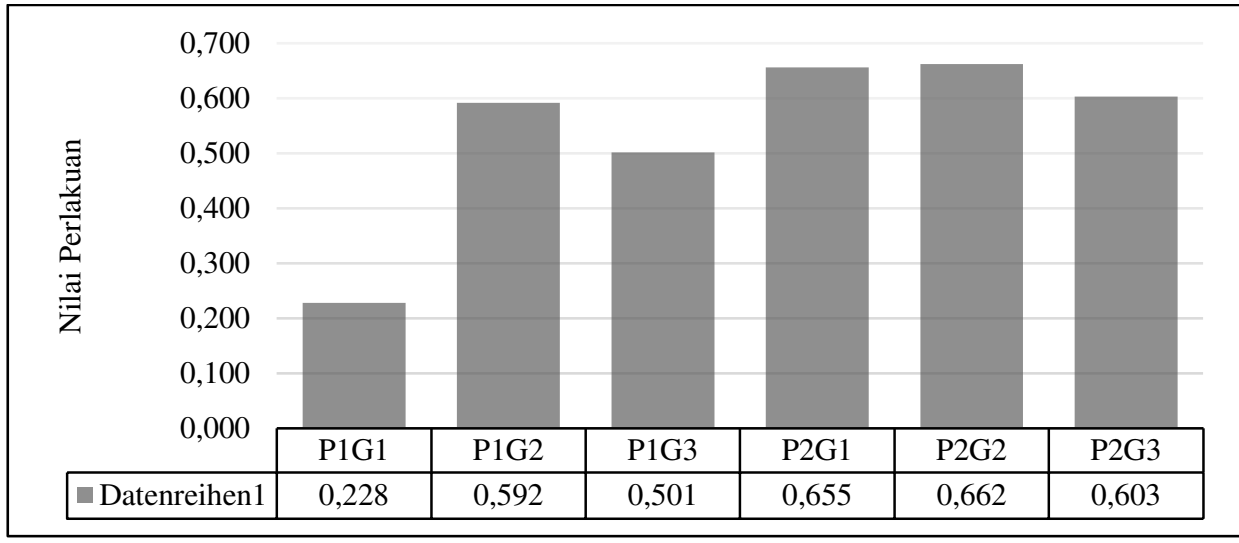

Keterangan : P1 X G1 = Proposi pektin 40gram dan 0gram /300gram ekstrak carica

P1 X G2 = Proposi pektin 40gram dan gula 20gram / 300gram ekstrak carica

P1 X G3 = Proposi pektin 40gram dan gula 50gram / 300gram ekstrak carica

P2 X G1 = Proposi pektin 60gram dan 0gram / 300gram ekstrak carica

P2 X G2 = Proposi pektin 60gram dan gula 20gram / 300gram ekstrak carica

P2 X G3 = Proposi pektin 60gram dan gula 50gram / 300gram ekstrak carica

Gambar 5 . Grafik perlakuan terbaik

\section{KESIMPULAN DAN SARAN}

\section{Kesimpulan}

Dari penelitian yang sudah dilakukan dapat di simpulkan bahwasannya :

1. Proporsi pektin dan gula terbaik untuk menghasilkan permen jelly carica dari sifat fisikokimiawi hasil analisa indek efektivitas fisikokimiawi terdapat pada perlakuan P2G3 (poporsi pektin $60 \mathrm{gr}$ dan gula 50 gr) yaitu kadar air dengan nilai $60,83 \%$, total gula dengan nilai $12,40 \%$, Vitamin $\mathrm{C}$ dengan nilai 12,55 $\mathrm{mg} / 100 \mathrm{~g}$.

2. Proporsi pektin dan gula terbaik untuk menghasilkan permen jelly carica dari sifat organoleptik hasil analisa indek efektivitas organoleptik terdapat pada perlakuan P2G1 (pProporsi pektin $60 \mathrm{gr}$ dan gula 0 gr) yaitu Rasa dengan nilai 2,90 (netral), Aroma dengan nilai 3,45 (suka), Warna dengan nilai 3,70 (suka) dan Tekstur dengan nilai 3,95 (suka).

3. Proporsi pektin dan gula terbaik untuk menghasilkan permen jelly carica dari sifat fisikokimiawi dan organoleptik hasil analisa indek efektifitas terdapat pada perlakuan P2G2 proporsi pektin 60 gr dan gula 20 gr) yaitu kadar air dengan nilai $65,06 \%$, total gula dengan nilai $7,74 \%$, vtamin $\mathrm{C}$ dengan nilai 11,50 $\mathrm{mg} / 100 \mathrm{~g}$, rasa dengan nilai 3,55 (netral), aoma dengan nilai 3,25 (netral), Warna dengan nilai 3,60 (netral) dan Tekstur dengan nilai 3,50 netral.

\section{Saran}

Untuk kesempurnaan dan pengembangan hasil penelitian ini maka disarankan:

1. Untuk melakukan penelitian kandungan yang lain permen jelly carica dari perbandingan pektin dan gula dengan menggunakan metode yang berbeda.

2. Untuk melakukan penelitian dan pengujian dengan menggunakan bahan tambahan herbal lain agar menambah nilai sebagai makanan fungsional.

\section{DAFTAR PUSTAKA}

Afriani, Suryono dan Lukman Haris. (2011). Karakteristik Dadih Susu Sapi Hasil Fermentasi Beberapa Starter Bakteri Asam Laktat Yang Diisolasi Dari Dadih Asal Kabupaten Kerinci. Jurnal Agrinak, 1(1).

Afriani, Suryono dan Lukman Haris. (2011). Karakteristik Dadih Susu Sapi Hasil Fermentasi Beberapa Starter Bakteri Asam Laktat Yang Diisolasi 
Dari Dadih Asal Kabupaten Kerinci. Jurnal Agrinak 1 (1).

Almahbub, A.S., (2017). Pengaruh Proporsi Kayu Secang (Caesalpinia Sappan L.) dan Kayu Manis (Cinnamomum Burmanii Bl) Terhadap Aktivitas Antioksidan "Wedang Semanis"., Skripsi., Fakultas Pertanian., Universitas Yudharta.,

Davey, M. W, Kenis, K., \& Keulemans, J. (2006). Genetic Control of Fruit Vitamin C Contents. Plant Physiology 142: 343-351.

Eskin N.A.M, Henderson H.M, Townseed R.L. (1971). Biokhemistry of Food. Academic Press, New York.

Geleta, G.S \& Bekele, D.A. (2015). Iodometric Determination of the Ascorbic Acid (Vitamin C) content of some Fruits consumed in Jimma Town Community in Ethiopia. Research Journal of Chemical Sciences, 5(1): 60-63

Handbook Spectrofotometry. (2017). www.gelifesciences.com, 19 April 2017.

Jacob, Robert A. (2005). Vitamin C. In : Modern Nutrition in Health and Disease 1. Ten edition. A. Waverly Company. Lea \& Febiger. Philadelphia.

Khopkar, S. M. (1990). Konsep dasar kimia analitik. Jakarta: UI Press.

Lumbessy,Mirna. Dkk. (2013). Uji total Flavonoid pada beberapa tanaman obat tradisional diwaitina Kecamatan Mangoli Timur Kabupaten Kepulauan Sula, Maluku Timur. Jurnal MIPA UNSRAT., 2 (1): :50-55

Malik, I., (2010). Permen Jelly. https://iwanmalik.wordpress.com/201 0/04/22/permen-jelly/ [diakses : 18 Maret 2018].

Minarno, Eko Budi. (2015). Skrining Fitokimia dan Kandungan Total Flavanoid pada Buah Carica pubescens Lenne \& K. Koch di Kawasan Bromo, Cangar, dan Dataran Tinggi Dieng. El-Hayah Vol. 5 (2) : 73-83.

Nasoetion, A. H. \& Karyadi, D. (1987). Vitamin. PT. Gramedia. Jakarta

Neswati. (2013). Karakteristik Permen Jelly Pepaya (Carica Papaya L.) dengan Penambahan Gelatin Sapi. Fakultas Teknologi Pertanian, Universitas Andalas. Padang.

Padayatty, S.J., Katz, A., Wang, Y., Eck, P., Kwon, O., Lee, J.H., Chen, S., Corpe, C., Dutta, A., Dutta, S.K., FACN., \& Levine, Mark. (2003). Vitamin C as an Antioxidant: Evaluation of Its Role in Disease Prevention. Journal of the American College of Nutrition 1 (22):18-35.

Pancoast, H.M dan W. Ray. Junk. (1980). Hand Book of Sugars. Second edition. The AVI Publishing Company Inc. Westport, Connecticut.

Pratama, S. B., Wijana, S., \& Febrianto, A. (2013). Studi Pembuatan Sirup Tamarillo (Kajian Perbandingan Buah Dan Konsentrasi Gula). Jurnal Industria, 1(3).

Salamah, E., Erungan, A. C., \& Retnowati, Y. (2006). Pemanfaatan Gracilaria sp. dalam pembuatan permen jelly.

Suanto,T dan Saneto, B. (1994). Teknologi Pengolahan Hasil Pertanian. PT Bina Ilmu. Surabaya.

Winarno, F.G. dan S. Laksmi. (1984). Pigmen dalam Pengolahan Pangan, Dept. THP. Fatemeta IPB, Bogor. 